\title{
KARAKTERISTIK-KARAKTERISTIK DASAR PEMBAYAR DIVIDEN
}

\author{
Winston Pontoh \\ (Email : winston_pontoh@yahoo.com)
}

\begin{abstract}
Financial factors is still the basic consideration for most companies to decide their dividend policy. Generally, dividend policy is a reflection of successful financial performance by companies in terms to perform profitability, investment opportunities, and size, related to basic financial factors which are assets, liabilities, and equities. The objective of this study is to give the empirical evidence about the relationship of basic financial factors with dividend policy. The study taking 373 listed companies in Indonesia Stock Exchange in period of 2010 till 2012, and using multinomial logistic regression for hypothesis testing. This study is find that, expect fixed assets, total assets, total liabilities, retained earnings, revenue and net earnings have significant effect to dividend policy, while fixed assets has not significant effect to dividend policy.
\end{abstract}

Keywords : aset tetap, total aset, total liabilitas, laba ditahan, pendapatan, laba bersih

\section{Pendahuluan}

Kebijakan dividen masih menjadi isu hangat dalam kajian-kajian ilmiah yang disebabkan karena adanya berbagai pertimbangan mendasar dari pemegang saham dan pihak internal korporat yang melandasi keputusan pembayaran dividen tersebut. Dividen dipandang sebagai sebuah simbol kesejahteraan bagi para pemegang saham (Asquith dan Mullins, 1986), sebaliknya bagi pihak internal korporat, dividen juga dipandang sebuah sumber pembiayaan yang baru (Bernheim, 1991), sehingga pembayaran dividen dipandang sebagai pengeluaran kas yang dapat mengurangi peluang terjadinya investasi yang akan menimbulkan keuntungan di kemudian hari (Barnea, Haugen, dan Senbet, 1981).

Dasar dari sebuah keputusan atas pembayaran dividen seringkali melihat kualitas dari korporat itu sendiri (Bernheim, 1991). Sehingga secara umum, keputusan untuk membayar dividen adalah merupakan sebuah refleksi keberhasilan kinerja keuangan dari korporat tersebut, yaitu profitabilitas, peluang investasi dan ukuran perusahaan (Fama dan French, 2001) yang erat terkait dengan faktor-faktor keuangan dasar, yaitu aset, liabilitas dan ekuitas (Baker dan Wurgler, 2004).

Penelitian ini bertujuan untuk mengetahui faktor-faktor keuangan dasar yang merupakan karakteristik-karakteristik dasar sebuah korporat dalam mengambil keputusan untuk membayar dividen. Beberapa faktor-faktor keuangan dasar yang akan digunakan dalam penelitian ini terkait dengan kebijakan dividen sebuah korporat adalah aset tetap, total aset, total liabilitas, saldo laba (laba ditahan), tingkat pendapatan, dan laba bersih.

\section{Tinjauan Pustaka}

Perubahan dividen dari sebuah perusahaan yang memiliki tingkat investasi yang baik dan batasan likuiditas yang baik pula akan memberikan sebuah informasi yang lebih baik kepada investor tentang kemungkinan perubahan tingkat investasi dimasa depan yang berarti akan akan memberikan prospek pertumbuhan laba yang lebih baik pula di masa yang akan datang. Perusahaan-perusahaan yang termasuk dalam perusahaan yang terus meningkatkan dividen pada umumnya memiliki tingkat investasi yang lebih tinggi apabila dibandingkan dengan perusahaan-perusahaan yang tidak membayar dividen atau tidak mengalami perubahan nilai di dalam pembayaran dividennya. Sebaliknya, perusahaan yang mengalami penurunan nilai dividen, pada umumnya akan menurunkan nilai aset tetapnya pada tahun pertama setelah adanya pengumuman atas pembayaran dividen. Hal ini menunjukkan bahwa, perusahaan 
yang mengalami penurunan nilai dividen, mengalami penurunan laba bersih sehingga tidak memiliki jumlah uang tunai yang cukup untuk melanjutkan peningkatan investasi mereka. Bahkan, perusahaan-perusahaan ini cenderung untuk menjual aset tetap mereka yang tidak efisien lagi untuk mendukung kecukupan atas uang tunai yang dibutuhkan. Akan tetapi, hal ini akan mengalami perubahan, pada saat target laba bersih tahun kedua dan ketiga mereka tercapai yang memiliki dampak normalnya kembali aktivitas investasi mereka (Kato, Loewenstein, dan Tsay, 2002).

Hasil penelitian dari Holt (2003), menemukan bahwa hubungan antara investasi sebuah perusahaan dengan kebijakan dividennya adalah secara terbalik dan dikontrol oleh kendala keuangan perusahaan itu sendiri. Pendapat serupa diajukan oleh Strebulaev dan Yang (2013), yang menyatakan bahwa sebuah perusahaan yang membayarkan dividennya dengan nilai yang lebih tinggi adalah ciri khas sebuah perusahaan yang memiliki profitabilitas yang tinggi, memiliki beban pajak yang lebih tinggi, menerbitkan modal saham yang lebih sedikit, dan memiliki tingkat keseimbangan uang tunai yang lebih tinggi, serta didukung oleh ukuran perusahaan itu sendiri.

Voutsinas dan Werner (2011) berpendapat bahwa, perusahaan yang memiliki aset tetap berwujud yang cukup dibandingkan dengan aset tetap tak berwujud akan memiliki informasi asimetris yang lebih sedikit, karena nilai aset tetap yang dimilikinya akan dapat menangkal masalah kebangkrutan. Hal ini didukung dengan bukti empiris yang ditemukan bahwa adanya peningkatan aset tetap akan memberikan pengaruh atas penentuan struktur modal baik berupa kebijakan utang maupun kebijakan penerbitan modal saham, walaupun hasil temuan menunjukkan bahwa kebijakan untuk menerbitkan modal saham adalah lebih kuat. Selain itu, apabila sebuah perusahaan memiliki aset tetap yang tinggi, maka ketergantungan perusahaan tersebut pada pembiayaan eksternal akan berkurang. Koch dan Shenoy (1999) berpendapat bahwa, dividen dan kebijakan struktur modal akan saling berinteraksi untuk menyediakan informasi prediktif yang signifikan tentang arus kas masa depan. Fama dan Babiak (1968), serta, Agrawal dan Jayaraman (1994), menyatakan bahwa kebijakan utang erat kaitannya dengan kebijakan dividen, terlebih jika dikaitkan dengan masalah keagenan.

Delen, Kuzey, dan Uyar (2013) berpendapat bahwa, sebuah perusahaan akan memperoleh kesuksesan dengan menghasilkan pendapatan lewat pemanfaatan asetnya, pengumpulan piutangnya, dan penjualan persediaannya hingga mencapai profitabilitas yang ingin dicapai. Pendapat ini didukung oleh Amidu (2007), yang menemukan bahwa adanya hubungan positif antara tingkat pengembalian aset dengan kebijakan dividen yang disertai dengan pertumbuhan pendapatan penjualan. Selain itu, ditemukan bahwa, perusahaan yang memiliki ukuran yang lebih besar akan menghasilkan tingkat pengembalian aset yang lebih sedikit sehingga menciptakan hubungan negatif antara tingkat pengembalian aset dengan kebijakan dividen dan kebijakan utang. Hal yang serupa juga ditemukan sebelumnya oleh Nissim dan Ziv (2001), dimana dividen mempunyai hubungan yang erat dengan laba bersih. Hasil pendukung yang sama disampaikan oleh Lie (2005), dimana adanya perubahan pada laba bersih akan mengakibatkan peningkatan atau penurunan pembayaran dividen.

\section{Hipotesis dan Model}

Adapun hipotesis dalam penelitian ini disusun sebagai berikut :

$\mathrm{Ha}_{1}$ : Aset tetap berpengaruh signifikan terhadap kebijakan dividen.

$\mathrm{Ha}_{2}$ : Total aset berpengaruh signifikan terhadap kebijakan dividen.

$\mathrm{Ha}_{3}$ : Total liabilitas berpengaruh signifikan terhadap kebijakan dividen.

$\mathrm{Ha}_{4}$ : Laba ditahan berpengaruh signifikan terhadap kebijakan dividen.

$\mathrm{Ha}_{5}$ : Pendapatan berpengaruh signifikan terhadap kebijakan dividen.

$\mathrm{Ha}_{6}$ : Laba bersih berpengaruh signifikan terhadap kebijakan dividen. 
Sedangkan model persamaan dalam penelitian ini disusun sebagai berikut :

Dividen $_{\text {Dummy }}=\alpha+\beta \ln \mathrm{AT}+\beta \operatorname{lnTA}+\beta \operatorname{lnTL}+\beta \ln \mathrm{LD}+\beta \ln P e n d+\beta \ln \mathrm{LB}$

\section{Metode Penelitian}

\subsection{Data}

Data dalam penelitian ini mengambil 373 perusahaan yang terdaftar dalam Bursa Efek Indonesia pada periode tahun 2010 sampai dengan tahun 2012, sehingga data observasi dalam penelitian ini secara keseluruhan adalah berjumlah 1,119 data observasi.

\subsection{Variabel dan Pengukuran Variabel}

Variabel yang digunakan dalam penelitian ini terdiri atas variabel dependen dan variabel independen. Variabel dependen adalah pembayar dividen yang diukur dengan dummy yang memiliki klasifikasi sebagai berikut :

1. Perusahaan yang tidak membayar dividend selama 3 (tiga) tahun atau K0.

2. Perusahaan yang membayar dividen hanya 1 (satu) tahun atau K1.

3. Perusahaan yang membayar dividen hanya 2 (dua) tahun atau K2.

4. Perusahaan yang membayar dividen secara penuh selama 3 (tiga) tahun atau K3.

Sedangkan variabel independen yang digunakan dalam penelitian ini adalah aset tetap, total aset, total liabilitas, saldo laba (laba ditahan), tingkat pendapatan, dan laba bersih, dimana variabel-variabel ini diukur dengan nilai rupiah yang dinormalisasi dengan logaritma natural.

\subsection{Metode Analisis}

Dalam penelitian ini, metode analisis yang akan digunakan untuk pengujian hipotesis adalah dengan menggunakan uji regresi logistik multinomial, dimana dalam alat uji ini, akan didukung oleh uji kelayakan model (model fitting criteria), uji kelayakan data atas model (goodness of fit), determinasi model (pseudo R-square), efek setiap variabel independen (likelihood ratio tests), dan estimasi koefisien atas persamaaan yang dihasilkan (parameter estimates).

\section{Hasil Analisis dan Pembahasan}

\subsection{Hasil Analisis}

Berdasarkan hasil analisis, statistik deskriptif tentang jumlah data observasi berdasarkan klasifikasi perusahaan pembayar dividen untuk setiap sektor yang terdaftar dalam Bursa Efek Indonesia disajikan pada Tabel 1 .

Tabel 1. Data Observasi

\begin{tabular}{lrrrrrr}
\hline \multirow{2}{*}{ Sector } & \multicolumn{3}{c}{ Kode Pembayar Dividen } & \multicolumn{2}{c}{ Total } \\
\cline { 2 - 5 } & \multicolumn{1}{c}{$\mathbf{0}$} & \multicolumn{1}{c}{$\mathbf{1}$} & \multicolumn{1}{c}{$\mathbf{2}$} & $\mathbf{3}$ & \multicolumn{2}{c}{ Observasi } \\
\hline Agriculture & 18 & 0 & 3 & 21 & 42 \\
Mining & 30 & 12 & 12 & 27 & 81 \\
Basic Industry \& Chemicals & 72 & 24 & 21 & 51 & 168 \\
Miscellaneous Industry & 57 & 6 & 18 & 30 & 111 \\
Consumer Goods Industry & 24 & 9 & 9 & 45 & 87 \\
Property, Real Estate, and Building Construction & 45 & 12 & 18 & 42 & 117 \\
Infrastructure, Utilities, and Transportation & 48 & 6 & 6 & 18 & 78 \\
Finance & 72 & 30 & 15 & 63 & 180 \\
Trade, Service, Investment & 123 & 21 & 30 & 81 & 255 \\
\hline Total & $\mathbf{4 8 9}$ & $\mathbf{1 2 0}$ & $\mathbf{1 3 2}$ & $\mathbf{3 7 8}$ & $\mathbf{1 , 1 1 9}$ \\
\hline
\end{tabular}


Selanjutnya, berdasarkan hasil analisis, statistik deskriptif juga menyajikan nilai tengah (mean value) setiap faktor-faktor keuangan dasar untuk setiap perusahaan pembayar dividen dalam rentang periode tahun 2010 sampai dengan 2012, seperti yang disajikan dalam Tabel 2.

Tabel 2. Nilai Tengah Faktor-Faktor Keuangan setiap Pembayar Dividen (dalam Rupiah)

\begin{tabular}{lrrrr}
\hline \multicolumn{1}{c}{ Faktor } & \multicolumn{1}{c}{ K0 } & \multicolumn{1}{c}{ K1 } & \multicolumn{1}{c}{ K2 } & \multicolumn{1}{c}{ K3 } \\
\hline Aset Tetap & $956,809.65$ & $1,092,329.39$ & $5,582,303.90$ & $3,234,609.64$ \\
Total Aset & $5,724,233.23$ & $8,764,965.98$ & $6,573,409.69$ & $25,264,665.83$ \\
Total Liabilitas & $4,376,985.80$ & $6,914,273.84$ & $4,092,768.32$ & $18,645,257.61$ \\
Laba Ditahan & $-174,663.24$ & $710,058.30$ & $798,465.77$ & $4,041,696.56$ \\
Pendapatan & $1,402,547.10$ & $2,724,330.78$ & $4,774,695.29$ & $9,284,514.13$ \\
Laba Bersih & $20,585.02$ & $250,758.92$ & $296,671.30$ & $1,486,028.37$ \\
\hline
\end{tabular}

\subsection{Pembahasan}

Berdasarkan hasil analisis, nilai Chi Square dari model final adalah 476.104 dengan tingkat signifikansi berada di bawah 5\%, sehingga dapat disimpulkan bahwa model final yang dihasilkan adalah fit (lihat Tabel 3).

Tabel 3. Model Fitting Information

\begin{tabular}{lrrrr}
\hline \multirow{2}{*}{ Model } & \multicolumn{3}{c}{ Model Fitting Criteria } & \multicolumn{3}{c}{ Likelihood Ratio Tests } \\
\cline { 2 - 5 } & $\mathbf{- 2}$ Log Likelihood & Chi-Square & df & \multicolumn{1}{c}{ Sig. } \\
\hline Intercept Only & 2730.219 & & & \\
Final & 2254.114 & 476.104 & 18 & 0.000 \\
\hline
\end{tabular}

Selain itu, nilai Chi Square dari deviance menunjukkan signifikansi yang berada diatas 5\%, sehingga hal ini membuktikan bahwa data penelitian adalah fit dengan model akhir (lihat Tabel 4).

Tabel 4. Goodness-of-Fit

\begin{tabular}{|c|c|c|c|}
\hline & Chi-Square & df & Sig. \\
\hline Pearson & 3192.185 & 3336 & 0.962 \\
\hline Deviance & 2254.114 & 3336 & 1.000 \\
\hline
\end{tabular}

Nilai pseudo R-Square (lihat Tabel 5) menunjukkan bahwa kontribusi variabel independen untuk menjelaskan model final dari variabel dependen adalah sebesar $34.7 \%$ (Cox and Snell), 38\% (Nagelkerke), dan 17.4\% (McFadden).

Tabel 5. Pseudo R-Square

\begin{tabular}{ll}
\hline Cox and Snell & 0.347 \\
Nagelkerke & 0.380 \\
McFadden & 0.174 \\
\hline
\end{tabular}

Kontribusi variabel independen ini didukung oleh hasil pengujian likelihood ratio (lihat Tabel 6), yang menunjukkan bahwa, kecuali nilai total aset (lnTA), variabel independen lainnya memiliki kontribusi untuk menjelaskan model final, dengan tingkat signifikansi berada di bawah $5 \%$. 
Tabel 6. Likelihood Ratio Tests

\begin{tabular}{lcrrr}
\hline \multirow{2}{*}{ Effect } & Model Fitting Criteria & \multicolumn{2}{c}{ Likelihood Ratio Tests } \\
\cline { 2 - 5 } & $\mathbf{- 2 ~ L o g ~ L i k e l i h o o d ~ o f ~ R e d u c e d ~ M o d e l ~}$ & Chi-Square & df & \multicolumn{1}{c}{ Sig. } \\
\hline Intercept & 2465.452 & 211.338 & 3 & 0.000 \\
LnAT & 2262.792 & 8.678 & 3 & 0.034 \\
LnTA & 2255.253 & 1.138 & 3 & 0.768 \\
LnTL & 2275.471 & 21.357 & 3 & 0.000 \\
LnLD & 2286.282 & 32.168 & 3 & 0.000 \\
LnPend & 2394.403 & 140.289 & 3 & 0.000 \\
LnLB & 2307.074 & 52.960 & 3 & 0.000 \\
\hline
\end{tabular}

Berdasarkan hasil regresi logistik multinomial, maka beberapa model persamaan yang diperoleh berdasarkan Tabel 7 adalah sebagai berikut :

$$
\begin{aligned}
& \operatorname{Div}_{0 / 3}=10.370+0.163 \mathrm{AT}-0.060 \mathrm{TA}+0.551 \mathrm{TL} \\
& -0.047 \mathrm{LD}-0.846 \mathrm{Pend}-0.565 \mathrm{LB} \\
& \operatorname{Div}_{0 / 2}=7.983+0.029 \mathrm{AT}+0.163 \mathrm{TA}+0.165 \mathrm{TL} \\
& +0.419 \mathrm{LD}-0.964 \text { Pend }-0.327 \mathrm{LB} \\
& +0.297 \mathrm{LD}-0.432 \text { Pend }-0.148 \mathrm{LB} \\
& -0.343 \mathrm{LD}-0.414 \text { Pend }-0.417 \mathrm{LB} \\
& +0.122 \mathrm{LD}-0.532 \mathrm{Pend}-0.178 \mathrm{LB} \\
& -0.466 \mathrm{LD}+0.118 \text { Pend }-0.239 \mathrm{LB}
\end{aligned}
$$

\begin{tabular}{|c|c|c|c|c|c|c|c|}
\hline & & B & Std. Error & Wald & df & Sig. & $\operatorname{Exp}(B)$ \\
\hline \multirow[t]{7}{*}{$\mathrm{K} 0 * * *$} & Intercept & 10.370 & 0.838 & 152.964 & 1 & 0.000 & \\
\hline & AT & 0.163 & 0.057 & 8.216 & 1 & 0.004 & 1.177 \\
\hline & TA & -0.060 & 0.152 & 0.158 & 1 & 0.691 & 0.941 \\
\hline & TL & 0.551 & 0.124 & 19.821 & 1 & 0.000 & 1.735 \\
\hline & LD & -0.047 & 0.084 & 0.312 & 1 & 0.576 & 0.954 \\
\hline & Pend & -0.846 & 0.091 & 87.299 & 1 & 0.000 & 0.429 \\
\hline & LB & -0.565 & 0.085 & 44.702 & 1 & 0.000 & 0.568 \\
\hline \multirow[t]{7}{*}{$\mathrm{K} 0 * *$} & Intercept & 7.983 & 1.102 & 52.513 & 1 & 0.000 & \\
\hline & $\mathrm{AT}$ & 0.029 & 0.076 & 0.143 & 1 & 0.705 & 1.029 \\
\hline & TA & 0.163 & 0.238 & 0.470 & 1 & 0.493 & 1.177 \\
\hline & $\mathrm{TL}$ & 0.165 & 0.192 & 0.745 & 1 & 0.388 & 1.180 \\
\hline & LD & 0.419 & 0.098 & 18.355 & 1 & 0.000 & 1.520 \\
\hline & Pend & -0.964 & 0.125 & 59.671 & 1 & 0.000 & 0.381 \\
\hline & LB & -0.327 & 0.102 & 10.239 & 1 & 0.001 & 0.721 \\
\hline \multirow[t]{7}{*}{$\mathrm{K} 0 *$} & Intercept & 3.805 & 1.019 & 13.952 & 1 & 0.000 & \\
\hline & AT & 0.035 & 0.069 & 0.258 & 1 & 0.611 & 1.036 \\
\hline & TA & -0.101 & 0.196 & 0.263 & 1 & 0.608 & 0.904 \\
\hline & TL & 0.168 & 0.161 & 1.088 & 1 & 0.297 & 1.183 \\
\hline & LD & 0.297 & 0.086 & 11.960 & 1 & 0.001 & 1.345 \\
\hline & Pend & -0.432 & 0.109 & 15.696 & 1 & 0.000 & 0.649 \\
\hline & LB & -0.148 & 0.087 & 2.929 & 1 & 0.087 & 0.862 \\
\hline
\end{tabular}

Tabel 7. Parameter Estimates 
Tabel 7. Parameter Estimates (lanjutan)

\begin{tabular}{|c|c|c|c|c|c|c|c|}
\hline & & B & Std. Error & Wald & df & Sig. & $\operatorname{Exp}(B)$ \\
\hline \multirow[t]{7}{*}{$\mathrm{K} 1 * * *$} & Intercept & 6.565 & 1.113 & 34.767 & 1 & 0.000 & \\
\hline & AT & 0.128 & 0.076 & 2.810 & 1 & 0.094 & 1.136 \\
\hline & TA & 0.040 & 0.216 & 0.034 & 1 & 0.853 & 1.041 \\
\hline & TL & 0.383 & 0.173 & 4.866 & 1 & 0.027 & 1.466 \\
\hline & LD & -0.343 & 0.103 & 11.093 & 1 & 0.001 & 0.709 \\
\hline & Pend & -0.414 & 0.121 & 11.774 & 1 & 0.001 & 0.661 \\
\hline & LB & -0.417 & 0.107 & 15.320 & 1 & 0.000 & 0.659 \\
\hline \multirow[t]{7}{*}{$\mathrm{K} 1 * *$} & Intercept & 4.178 & 1.315 & 10.101 & 1 & 0.001 & \\
\hline & $\mathrm{AT}$ & -0.006 & 0.091 & 0.005 & 1 & 0.946 & 0.994 \\
\hline & TA & 0.263 & 0.280 & 0.886 & 1 & 0.347 & 1.301 \\
\hline & TL & -0.003 & 0.226 & 0.000 & 1 & 0.990 & 0.997 \\
\hline & LD & 0.122 & 0.112 & 1.188 & 1 & 0.276 & 1.130 \\
\hline & Pend & -0.532 & 0.146 & 13.220 & 1 & 0.000 & 0.587 \\
\hline & LB & -0.178 & 0.120 & 2.226 & 1 & 0.136 & 0.837 \\
\hline \multirow[t]{7}{*}{$\mathrm{K} 2 * * *$} & Intercept & 2.387 & 1.108 & 4.638 & 1 & 0.031 & \\
\hline & AT & 0.134 & 0.079 & 2.886 & 1 & 0.089 & 1.143 \\
\hline & TA & -0.223 & 0.244 & 0.840 & 1 & 0.359 & 0.800 \\
\hline & TL & 0.385 & 0.193 & 3.986 & 1 & 0.046 & 1.470 \\
\hline & LD & -0.466 & 0.106 & 19.324 & 1 & 0.000 & 0.628 \\
\hline & Pend & 0.118 & 0.127 & 0.868 & 1 & 0.352 & 1.125 \\
\hline & LB & -0.239 & 0.111 & 4.615 & 1 & 0.032 & 0.788 \\
\hline
\end{tabular}

*Referensi Pembanding : K1.

**Referensi Pembanding : K2.

***Referensi Pembanding : K3.

Aset Tetap (AT). Model 1 menunjukkan bahwa aset tetap signifikan berpengaruh terhadap pembayaran dividen, dimana perusahaan yang membayar dividen dengan kode K0 memiliki probabilitas yang lebih tinggi $(\mathrm{p}=1.177)$ untuk membayar dividen dibandingkan dengan perusahaan yang membayar dividen dengan kode $\mathrm{K} 3$, ketika aset tetap mengalami peningkatan $(\beta=0.163)$. Model 2 menunjukkan bahwa aset tetap tidak signifikan berpengaruh terhadap pembayaran dividen, dimana perusahaan yang membayar dividen dengan kode K1 memiliki probabilitas yang lebih tinggi $(\mathrm{p}=1.136)$ untuk membayar dividen dibandingkan dengan perusahaan yang membayar dividen dengan kode $\mathrm{K} 3$, ketika aset tetap mengalami peningkatan $(\beta=0.128)$. Model 3 menunjukkan bahwa aset tetap tidak signifikan berpengaruh terhadap pembayaran dividen, dimana perusahaan yang membayar dividen dengan kode K2 memiliki probabilitas yang lebih tinggi $(\mathrm{p}=1.143)$ untuk membayar dividen dibandingkan dengan perusahaan yang membayar dividen dengan kode $\mathrm{K} 3$, ketika aset tetap mengalami peningkatan $(\beta=0.134)$. Model 4 menunjukkan bahwa aset tetap tidak signifikan berpengaruh terhadap pembayaran dividen, dimana perusahaan yang membayar dividen dengan kode K0 memiliki probabilitas yang lebih tinggi $(\mathrm{p}=1.036)$ untuk membayar dividen dibandingkan dengan perusahaan yang membayar dividen dengan kode $\mathrm{K} 1$, ketika aset tetap mengalami peningkatan $(\beta=0.035)$. Model 5 menunjukkan bahwa aset tetap tidak signifikan berpengaruh terhadap pembayaran dividen, dimana perusahaan yang membayar dividen dengan kode K0 memiliki probabilitas yang lebih tinggi $(\mathrm{p}=1.029)$ untuk membayar dividen dibandingkan dengan perusahaan yang membayar dividen dengan kode $\mathrm{K} 2$, ketika aset tetap mengalami peningkatan $(\beta=0.029)$. Model 6 menunjukkan bahwa aset tetap tidak signifikan berpengaruh terhadap pembayaran dividen, dimana perusahaan yang membayar dividen dengan kode K1 memiliki probabilitas yang lebih rendah $(\mathrm{p}=0.994)$ untuk membayar dividen dibandingkan dengan perusahaan yang membayar dividen dengan kode $\mathrm{K} 2$, ketika aset tetap mengalami penurunan $(\beta=-0.006)$. 
Total Aset (TA). Model 1 menunjukkan bahwa bahwa total aset tidak signifikan berpengaruh terhadap pembayaran dividen, dimana perusahaan yang membayar dividen dengan kode K0 memiliki probabilitas yang lebih rendah $(\mathrm{p}=0.941)$ untuk membayar dividen dibandingkan dengan perusahaan yang membayar dividen dengan kode $\mathrm{K} 3$, ketika total aset mengalami penurunan $(\beta=-0.060)$. Model 2 menunjukkan bahwa total aset tidak signifikan berpengaruh terhadap pembayaran dividen, dimana perusahaan yang membayar dividen dengan kode $\mathrm{K} 1$ memiliki probabilitas yang lebih tinggi $(\mathrm{p}=1.041)$ untuk membayar dividen dibandingkan dengan perusahaan yang membayar dividen dengan kode $\mathrm{K} 3$, ketika total aset mengalami peningkatan $(\beta=0.040)$. Model 3 menunjukkan bahwa total aset tidak signifikan berpengaruh terhadap pembayaran dividen, dimana perusahaan yang membayar dividen dengan kode $\mathrm{K} 2$ memiliki probabilitas yang lebih rendah $(\mathrm{p}=0.800)$ untuk membayar dividen dibandingkan dengan perusahaan yang membayar dividen dengan kode $\mathrm{K} 3$, ketika total aset mengalami penurunan $(\beta=-0.223)$. Model 4 menunjukkan bahwa total aset tidak signifikan berpengaruh terhadap pembayaran dividen, dimana perusahaan yang membayar dividen dengan kode $\mathrm{K} 0$ memiliki probabilitas yang lebih rendah $(\mathrm{p}=0.904)$ untuk membayar dividen dibandingkan dengan perusahaan yang membayar dividen dengan kode $\mathrm{K} 1$, ketika total aset mengalami penurunan $(\beta=-0.101)$. Model 5 menunjukkan bahwa total aset tidak signifikan berpengaruh terhadap pembayaran dividen, dimana perusahaan yang membayar dividen dengan kode $\mathrm{K} 0$ memiliki probabilitas yang lebih tinggi $(\mathrm{p}=1.177)$ untuk membayar dividen dibandingkan dengan perusahaan yang membayar dividen dengan kode $\mathrm{K} 2$, ketika total aset mengalami peningkatan $(\beta=0.163)$. Model 6 menunjukkan bahwa total aset tidak signifikan berpengaruh terhadap pembayaran dividen, dimana perusahaan yang membayar dividen dengan kode $\mathrm{K} 1$ memiliki probabilitas yang lebih tinggi $(\mathrm{p}=1.301)$ untuk membayar dividen dibandingkan dengan perusahaan yang membayar dividen dengan kode $\mathrm{K} 2$, ketika total aset mengalami peningkatan $(\beta=0.263)$.

Total Liabilitas (TL). Model 1 menunjukkan bahwa total liabilitas signifikan berpengaruh terhadap pembayaran dividen, dimana perusahaan yang membayar dividen dengan kode $\mathrm{K} 0$ memiliki probabilitas yang lebih tinggi $(\mathrm{p}=1.735)$ untuk membayar dividen dibandingkan dengan perusahaan yang membayar dividen dengan kode $\mathrm{K} 3$, ketika total liabilitas mengalami peningkatan $(\beta=0.551)$. Model 2 menunjukkan bahwa total liabilitas signifikan berpengaruh terhadap pembayaran dividen, dimana perusahaan yang membayar dividen dengan kode $\mathrm{K} 1$ memiliki probabilitas yang lebih tinggi $(\mathrm{p}=1.466)$ untuk membayar dividen dibandingkan dengan perusahaan yang membayar dividen dengan kode K3, ketika total liabilitas mengalami peningkatan $(\beta=0.383)$. Model 3 menunjukkan bahwa total liabilitas signifikan berpengaruh terhadap pembayaran dividen, dimana perusahaan yang membayar dividen dengan kode K2 memiliki probabilitas yang lebih tinggi ( $\mathrm{p}=1.470)$ untuk membayar dividen dibandingkan dengan perusahaan yang membayar dividen dengan kode $\mathrm{K} 3$, ketika total liabilitas mengalami peningkatan $(\beta=0.385)$. Model 4 menunjukkan bahwa total liabilitas tidak signifikan berpengaruh terhadap pembayaran dividen, dimana perusahaan yang membayar dividen dengan kode K0 memiliki probabilitas yang lebih tinggi $(\mathrm{p}=1.183$ ) untuk membayar dividen dibandingkan dengan perusahaan yang membayar dividen dengan kode $\mathrm{K} 1$, ketika total liabilitas mengalami peningkatan $(\beta=0.168)$. Model 5 menunjukkan bahwa total liabilitas tidak signifikan berpengaruh terhadap pembayaran dividen, dimana perusahaan yang membayar dividen dengan kode $\mathrm{K} 0$ memiliki probabilitas yang lebih tinggi $(\mathrm{p}=1.180)$ untuk membayar dividen dibandingkan dengan perusahaan yang membayar dividen dengan kode $\mathrm{K} 2$, ketika total liabilitas mengalami peningkatan $(\beta=0.165)$. Model 6 menunjukkan bahwa total liabilitas tidak signifikan berpengaruh terhadap pembayaran dividen, dimana perusahaan yang membayar dividen dengan kode $\mathrm{K} 1$ memiliki probabilitas yang lebih rendah $(\mathrm{p}=0.997)$ untuk membayar dividen dibandingkan dengan perusahaan yang membayar dividen dengan kode $\mathrm{K} 2$, ketika total liabilitas mengalami penurunan $(\beta=-0.003)$. 
Laba Ditahan (LD). Model 1 menunjukkan bahwa laba ditahan tidak signifikan berpengaruh terhadap pembayaran dividen, dimana perusahaan yang membayar dividen dengan kode K0 memiliki probabilitas yang lebih rendah $(\mathrm{p}=0.954)$ untuk membayar dividen dibandingkan dengan perusahaan yang membayar dividen dengan kode K3, ketika laba ditahan mengalami penurunan $(\beta=-0.047)$. Model 2 menunjukkan bahwa laba ditahan signifikan berpengaruh terhadap pembayaran dividen, dimana perusahaan yang membayar dividen dengan kode $\mathrm{K} 1$ memiliki probabilitas yang lebih rendah $(\mathrm{p}=0.709)$ untuk membayar dividen dibandingkan dengan perusahaan yang membayar dividen dengan kode K3, ketika laba ditahan mengalami penurunan $(\beta=-0.343)$. Model 3 menunjukkan bahwa laba ditahan signifikan berpengaruh terhadap pembayaran dividen, dimana perusahaan yang membayar dividen dengan kode $\mathrm{K} 2$ memiliki probabilitas yang lebih rendah $(\mathrm{p}=0.628)$ untuk membayar dividen dibandingkan dengan perusahaan yang membayar dividen dengan kode K3, ketika laba ditahan mengalami penurunan $(\beta=-0.466)$. Model 4 menunjukkan bahwa laba ditahan signifikan berpengaruh terhadap pembayaran dividen, dimana perusahaan yang membayar dividen dengan kode K0 memiliki probabilitas yang lebih tinggi $(\mathrm{p}=1.345)$ untuk membayar dividen dibandingkan dengan perusahaan yang membayar dividen dengan kode K1, ketika laba ditahan mengalami peningkatan $(\beta=0.297)$. Model 5 menunjukkan bahwa laba ditahan signifikan berpengaruh terhadap pembayaran dividen, dimana perusahaan yang membayar dividen dengan kode $\mathrm{K} 0$ memiliki probabilitas yang lebih tinggi $(\mathrm{p}=1.520)$ untuk membayar dividen dibandingkan dengan perusahaan yang membayar dividen dengan kode $\mathrm{K} 2$, ketika laba ditahan mengalami peningkatan $(\beta=0.419)$. Model 6 menunjukkan bahwa laba ditahan tidak signifikan berpengaruh terhadap pembayaran dividen, dimana perusahaan yang membayar dividen dengan kode $\mathrm{K} 1$ memiliki probabilitas yang lebih tinggi $(\mathrm{p}=1.130)$ untuk membayar dividen dibandingkan dengan perusahaan yang membayar dividen dengan kode $\mathrm{K} 2$, ketika laba ditahan mengalami peningkatan $(\beta=0.122)$.

Pendapatan (Pend). Model 1 menunjukkan bahwa pendapatan signifikan berpengaruh terhadap pembayaran dividen, dimana perusahaan yang membayar dividen dengan kode $\mathrm{K} 0$ memiliki probabilitas yang lebih rendah $(\mathrm{p}=0.429)$ untuk membayar dividen dibandingkan dengan perusahaan yang membayar dividen dengan kode K3, ketika pendapatan mengalami penurunan $(\beta=-0.846)$. Model 2 menunjukkan bahwa pendapatan signifikan berpengaruh terhadap pembayaran dividen, dimana perusahaan yang membayar dividen dengan kode K1 memiliki probabilitas yang lebih rendah $(\mathrm{p}=0.661)$ untuk membayar dividen dibandingkan dengan perusahaan yang membayar dividen dengan kode $\mathrm{K} 3$, ketika pendapatan mengalami penurunan $(\beta=-0.414)$. Model 3 menunjukkan bahwa pendapatan tidak signifikan berpengaruh terhadap pembayaran dividen, dimana perusahaan yang membayar dividen dengan kode $\mathrm{K} 2$ memiliki probabilitas yang lebih tinggi $(\mathrm{p}=1.125)$ untuk membayar dividen dibandingkan dengan perusahaan yang membayar dividen dengan kode K3, ketika pendapatan mengalami peningkatan $(\beta=0.118)$. Model 4 menunjukkan bahwa pendapatan signifikan berpengaruh terhadap pembayaran dividen, dimana perusahaan yang membayar dividen dengan kode $\mathrm{K} 0$ memiliki probabilitas yang lebih rendah $(\mathrm{p}=0.649)$ untuk membayar dividen dibandingkan dengan perusahaan yang membayar dividen dengan kode K1, ketika pendapatan mengalami penurunan $(\beta=-0.432)$. Model 5 menunjukkan bahwa pendapatan signifikan berpengaruh terhadap pembayaran dividen, dimana perusahaan yang membayar dividen dengan kode K0 memiliki probabilitas yang lebih rendah $(\mathrm{p}=0.381)$ untuk membayar dividen dibandingkan dengan perusahaan yang membayar dividen dengan kode K2, ketika pendapatan mengalami penurunan $(\beta=-0.964)$. Model 6 menunjukkan bahwa pendapatan signifikan berpengaruh terhadap pembayaran dividen, dimana perusahaan yang membayar dividen dengan kode $\mathrm{K} 1$ memiliki probabilitas yang lebih rendah $(\mathrm{p}=0.587)$ untuk membayar dividen dibandingkan dengan perusahaan yang membayar dividen dengan kode K2, ketika pendapatan mengalami penurunan $(\beta=-0.532)$. 
Laba Bersih (LB). Model 1 menunjukkan bahwa laba bersih signifikan berpengaruh terhadap pembayaran dividen, dimana perusahaan yang membayar dividen dengan kode K0 memiliki probabilitas yang lebih rendah $(\mathrm{p}=0.568)$ untuk membayar dividen dibandingkan dengan perusahaan yang membayar dividen dengan kode $\mathrm{K} 3$, ketika laba bersih mengalami penurunan $(\beta=-0.565)$. Model 2 menunjukkan bahwa laba bersih signifikan berpengaruh terhadap pembayaran dividen, dimana perusahaan yang membayar dividen dengan kode K1 memiliki probabilitas yang lebih rendah $(\mathrm{p}=0.659)$ untuk membayar dividen dibandingkan dengan perusahaan yang membayar dividen dengan kode $\mathrm{K} 3$, ketika laba bersih mengalami penurunan $(\beta=-0.417)$. Model 3 menunjukkan bahwa laba bersih signifikan berpengaruh terhadap pembayaran dividen, dimana perusahaan yang membayar dividen dengan kode K2 memiliki probabilitas yang lebih rendah $(\mathrm{p}=0.788)$ untuk membayar dividen dibandingkan dengan perusahaan yang membayar dividen dengan kode K3, ketika laba bersih mengalami penurunan $(\beta=-0.239)$. Model 4 menunjukkan bahwa laba bersih tidak signifikan berpengaruh terhadap pembayaran dividen, dimana perusahaan yang membayar dividen dengan kode K0 memiliki probabilitas yang lebih rendah $(\mathrm{p}=0.862)$ untuk membayar dividen dibandingkan dengan perusahaan yang membayar dividen dengan kode $\mathrm{K} 1$, ketika laba bersih mengalami penurunan $(\beta=-0.148)$. Model 5 menunjukkan bahwa laba bersih signifikan berpengaruh terhadap pembayaran dividen, dimana perusahaan yang membayar dividen dengan kode K0 memiliki probabilitas yang lebih rendah $(\mathrm{p}=0.721)$ untuk membayar dividen dibandingkan dengan perusahaan yang membayar dividen dengan kode $\mathrm{K} 2$, ketika laba bersih mengalami penurunan ( $\beta=-0.327)$. Model 6 menunjukkan bahwa laba bersih tidak signifikan berpengaruh terhadap pembayaran dividen, dimana perusahaan yang membayar dividen dengan kode K1 memiliki probabilitas yang lebih rendah $(\mathrm{p}=0.837)$ untuk membayar dividen dibandingkan dengan perusahaan yang membayar dividen dengan kode $\mathrm{K} 2$, ketika laba bersih mengalami penurunan $(\beta=-0.178)$.

Berdasarkan hasil analisis, dapat diketahui bahwa aset tetap dan total aset sebuah perusahaan dapat berpengaruh signifikan dan juga dapat tidak berpengaruh signifikan terhadap kebijakan dividen sebuah perusahaan tergantung pada sebuah kondisi tertentu, dalam arti bahwa peningkatan sebuah aset baik dari segi aset tetap maupun secara keseluruhan dapat mengakibatkan peningkatan maupun penurunan pembayaran dividen yang diputuskan. Hasil penelitian ini dapat mendukung pendapat dari Kato, Loewenstein, dan Tsay (2002), Holt (2003), serta Delen, Kuzey, dan Uyar (2013). Hal yang sama juga berlaku untuk faktor utang (liabilitas), dimana utang dapat mempengaruhi atau tidak secara signifikan terhadap kebijakan dividen tergantung kondisi keuangan sebuah perusahaan seperti pendapat dari Voutsinas dan Werner (2011), Koch dan Shenoy (1999), Fama dan Babiak (1968), serta Agrawal dan Jayaraman (1994). Faktor lainnya seperti pendapatan, laba ditahan dan laba bersih, akan berperilaku yang sama dalam berkontribusi untuk menentukan kebijakan dividen sesuai dengan pendapat dari Strebulaev dan Yang (2013), Delen, Kuzey, dan Uyar (2013), Amidu (2007), Lie (2005), serta Nissim dan Ziv (2001).

\section{Kesimpulan}

Apabila dibandingkan dengan perusahaan-perusahaan K3, maka kebijakan dividen dari perusahaan-perusahaan K0 akan banyak dipengaruhi oleh aset tetap, total utang, pendapatan dan laba bersih. Sedangkan apabila dibandingkan dengan perusahaan-perusahaan K2, maka kebijakan dividen dari perusahaan-perusahaan K0 akan banyak dipengaruhi oleh laba ditahan, pendapatan dan laba bersih. Dan apabila dibandingkan dengan perusahaanperusahaan $\mathrm{K} 1$, maka kebijakan dividen perusahaan-perusahaan $\mathrm{K} 0$ akan banyak dipengaruhi oleh laba ditahan dan pendapatan.

Apabila dibandingkan dengan perusahaan-perusahaan K3, maka kebijakan dividen dari perusahaan-perusahaan K1 akan banyak dipengaruhi oleh utang, laba ditahan, pendapatan 
dan laba bersih. Sedangkan apabila dibandingkan dengan perusahaan-perusahaan K2, maka kebijakan dividen dari perusahaan-perusahaan K1 akan banyak dipengaruhi oleh pendapatan. Sedangkan untuk K2, apabila dibandingkan dengan perusahaan-perusahaan K3, maka kebijakan dividen akan banyak dipengaruhi oleh utang, laba ditahan, dan laba bersih.

\section{Daftar Pustaka}

Agrawal, A. dan Jayaraman, N. (1994). The Dividend Policies of All Equity Firms : A Direct Test of the Free Cash Flow Theory. Managerial and Decision Economics, 15, 139-148.

Amidu, M. (2007). How does dividend policy affect performance of the firm on Ghana Stock Exchange? Investment Management and Financial Innovations, 4(2), 103-112.

Asquith, P. dan Mullins, D. W., Jr. (1986). Signalling with Dividends, Stock Repurchases, and Equity Issues. Financial Management, 15(3), 27-44.

Baker, M. dan Wurgler, J. (2004). Appearing and disappearing dividends : The link to catering incentives. Journal of Financial Economics, 73, 271-288.

Barnea, A., Haugen, R. A., dan Senbet, L. W. (1981). Market Imperfections, Agency Problems, and Capital Structure: A Review. Financial Management, 10(3), 7-22.

Bernheim, B. D. (1991). Tax Policy and the Dividend Puzzle. The RAND Journal of Economics, 22(4), 455-476.

Delen, D., Kuzey, C., dan Uyar, A. (2013). Measuring firm performance using financial ratios: A decision tree approach. Expert Systems with Applications, 40(10), 3970-3983.

Fama, E. F. dan Babiak, H. (1968). Dividend Policy : An Empirical Analysis. Journal of the American Statistical Association, 63(324), 1132-1161.

Fama, E. F. dan French, K. R. (2001). Disappearing dividends: changing firm characteristics or lower propensity to pay? Journal of Financial Economics, 60, 3-43.

Holt, R. W. P. (2003). Investment and dividends under irreversibility and financial constraints. Journal of Economic Dynamics \& Control, 27, 467-502.

Koch, P. D. dan Shenoy, C. (1999). The Information Content of Dividend and Capital Structure Policies. Financial Management, 28(4), 16-35.

Lie, E. (2005). Operating performance following dividend decreases and omissions. Journal of Corporate Finance, 12, 27- 53.

Kato, H. K., Loewenstein, U., dan Tsay, W. (2002). Dividend policy, cash flow, and investment in Japan. Pacific-Basin Finance Journal, 10, 443- 473.

Nissim, D. dan Ziv, A. (2001). Dividend Changes and Future Profitability. The Journal of Finance, 56(6), 2111-2133.

Strebulaev, I. A., dan Yang, B. (2013). The mystery of zero-leverage firms. Journal of Financial Economics, 109, 1-23.

Voutsinas, K., dan Werner, R.A. (2011). Credit supply and corporate capital structure: Evidence from Japan. International Review of Financial Analysis, 20(5), 320-334. 